\title{
PENERAPAN FUNGSI MANAJEMEN PENYIARAN PADA PROGRAM TALKSHOW AIMAN DI KOMPAS TV JAKARTA
}

\author{
Siti Asiatun 1 \\ ${ }^{1}$ Program Studi Manajemen Produksi Berita, Jurusan Penyiaran ,STMM MMTC Yogyakarta \\ Email: sasiatun@yahoo.co.id
}

\begin{abstract}
ABSTRAK
Kompas TV sebagai stasiun swasta berita nasional Indonesia yang didirikan pada tanggal 09 September 2013 berhasil membawa pulang prestasi berupa piala penghargaan ajang Anugerah KPI 2019 kategori program acara talk show (berita) investigasi, yakni talk show Aiman. Tujuan Penelitian adalah untuk mengetahui penerapan fungsi manajemen penyiaran pada program talk show Aiman di Kompas TV Jakarta,. Peneliti menggunakan jenis metode penelitian kualitatif dengan cara data-data yang dianalisis secara kualitatif akan dikelompokkan dan diseleksi berdasarkan kualitas dan kebenarannya yang berkaitan dengan masalah yang diteliti. . Fungsi perencanaan isi program acara dilakukan dengan riset yg mendalam dan penuh kehati-hatian. Fungsi pengorganisasian diatur sesuai dengan undang-undang nomor 40 tentang pers, tidak ada pembagian manajemen di bagian atas, tengah, dan bawah.. Fungsi pengarahan dan memberikan pengaruh yang diberikan pemimpin kepada bawahannya melalui metode motivasi, komunikasi, kepemimpinan, dan pelatihan. 1. Ketiga fungsi diatas mesti harus dilakukan evalusi melalui fungsi pengawasan. Dalam menjalankan fungsi pengawasan, manajemen talk show AIMAN melakukan penilaian semester setiap 6 bulan sekali untuk mengevaluasi hasil pekerjaan dari atasan ke bawahannya. dapat disimpulkan bahwa fungsi manajemen penyiaran pada program acara talk show AIMAN yang ditayangkan Kompas TV sudah diterapkan dengan baik. Diharapkan program acara talk show AIMAN di Kompas TV dapat terus ditayangkan mengingat kebutuhan masyarakat akan terangnya sebuah hot issues maupun current issues.
\end{abstract}

Kata Kunci: Manajemen, Aiman,Talkshow,Kompas TV.

\section{IMPLEMENTATION OF BROADCASTING MANAGEMENT FUNCTIONS IN THE TALKSHOW AIMAN PROGRAM AT KOMPAS TV JAKARTA}

\begin{abstract}
Kompas TV as a private Indonesian national news station, which was established on September 9, 2013, succeeded in bringing home an achievement in the form of an award trophy for the 2019 KPI Award in the category of investigative talk show (news) program, namely the Aiman talk show. The research objective was to determine the implementation of the broadcast management function in the Aiman talk show program on Kompas TV Jakarta,.. Researchers use this type of qualitative research method by means of qualitatively analyzed data will be grouped and selected based on quality and truth related to the problem under study. . The function of planning the program content is carried out with thorough and careful research. The organizing function is regulated in accordance with Law number 40 concerning the press, there is no division of management at the top, middle and bottom. The function of directing and exerting influence is given by leaders to their subordinates through methods of motivation, communication, leadership, and training. l. The three functions above must be evaluated through the supervisory function. In carrying out its supervisory function, talk show management AIMAN conducts semester assessments every 6 months to evaluate work results from superiors to subordinates. It can be concluded that the broadcasting management function in the AIMAN talk show program broadcast by Kompas TV has been implemented properly. It is hoped that the AIMAN talk show program on Kompas $T V$ can continue to be broadcast given the public's need to clarify hot issues and current issues.
\end{abstract}

Keywords: Management, Aiman, Talkshow, Kompas TV

Publish by Communication Science Program, Social Politic Faculty Universitas Muhammadiyah Buton. 
Korespondensi: Dra. Siti Asiatun., M.M. Program Studi Manajemen Multimedia, Sekolah Tinggi Multi Media Yogyakarta. Jalan Magelang Km. 6 Yogyakarta 55284. Indonesia Tel: (+62274) 561531, 562513. Fax: (+62274) 623537. No. HP, WhatsApp: $\mathbf{0 8 5 8 8 2 8 5 1 6 3 5}$ Email: sasiatun @yahoo.co.id

\section{PENDAHULUAN}

Media penyiaran merupakan organisasi yang menyebarkan informasi yang berupa produk budaya atau sebuah pesan yang dapat mempengaruhi dan mencerminkan budaya dalam masyarakat (Djamal, 2011:64).

Bila dikulik kebelakang mengenai perkembangan media penyiaran, menurut Morissan (2009:7), media penyiaran di Indonesia dimulai pada tahun 1975. Pada masa itu Profesor Komans dan Dr. De Groots dari pemerintah Hindia Belanda berhasil melakukan komunikasi radio dengan menggunakan stasiun relai di Malabar, Jawa Barat yang kemudian diikuti dengan berdirinya Batavia Radio Vereniging. Para ahli selanjutnya mengembangkan media penyiaran berupa televisi, yakni sebuah media massa yang sumber informasinya bukan hanya berasal dari suara, melainkan juga gambar yang bergerak sehingga informasi yang didapatkan para pemirsanya menjadi lebih lengkap.

Berdasarkan Pasal 13 Undang-Undang Penyiaran nomor 32 Tahun 2002 stasiun swasta adalah lembaga penyiaran yang bersifat komersial berbentuk badan hukum Indonesia yang bidang usahanya hanya menyelenggarakan jasa penyiaran radio dan televisi.

Guna mencapai tujuan tersebut stasiun swasta berlomba-lomba menciptakan program unggulan yang menarik banyak penonton sehingga dapat meningkatkan rating dan audience share. Rating merupakan hal yang penting karena pemasang iklan selalu mencari stasiun penyiaran atau program siaran yang paling banyak ditonton atau didengar orang (Morissan, 2009:342). Namun, hasil dari audience share juga tidak kalah penting dari rating. Jika rating dihitung berdasarkan jumlah keseluruhan televisi yang ada, entah sedang dimatikan atau tidak, maka audience share dihitung berdasarkan jumlah televisi yang tayangan programnya benar-benar sedang ditonton, sehingga calon pemasang iklan akan mengetahui secara lebih real mengenai posisi suatu program acara dengan program acara lain di stasiun televisi lainnya (Morissan, 2009:342).

. Di Indonesia, program-program acara televisi dan radio diawasi dan dibina oleh Komisi Penyiaran Indonesia (KPI) dibawah naungan Undang-Undang Penyiaran nomor 32 Tahun 2002. Komisi Penyiaran Indonesia setiap tahun menyelenggarakan ajang penganugerahan program acara televisi dan radio terbaik. Kompas TV sebagai stasiun swasta berita nasional Indonesia yang didirikan pada tanggal 09 September 2013 berhasil membawa pulang prestasi berupa piala penghargaan ajang Anugerah KPI 2019 kategori program acara talk show (berita) investigasi, yakni talk show Aiman (www.kpi.go.id/index.php/id/umum/38-dalamnegeri/35459-nama-pemenang-anugerah-kpi-2019). Talk show investigasi “Aiman” yang dipandu oleh Aiman Witjaksono berhasil dinilai membuktikan bahwa program acaranya dikemas dengan berkualitas dan memberikan nilai edukatif pada masyarakat.

. Menurut Wahyudi (1994:42), kegiatan manajemen penyiaran merupakan kegiatan manajemen yang khas mengingat organisasi penyiaran berbeda dengan organisasi pada umumnya,. Fungsi manajemen 
penyiaran sendiri adalah mengembangkan progam acaranya secara terstruktur, sehat dan nilai-nilai yang ditampilkan tersampaikan dengan baik sesuai dengan tujuan dan sasarannya. Untuk itu, dibutuhkan strategi penerapan fungsi manajemen penyiaran yang efektif pada program talk show Aiman di Kompas TV Jakarta agar prestasi yang telah diperoleh dapat menjadi bahan evaluasi yang lebih baik untuk kedepannya.

\section{METODE PENELITIAN}

\section{Jenis Penelitian}

Berdasarkan jenis data dan cara analisisnya, jenis penelitian ini merupakan penelitian kualitatif. Menurut Sugiyono, metode penelitian kualitatif sering disebut metode penelitian naturalistik karena penelitiannya dilakukan pada kondisi yang alamiah (natural) atau disebut juga sebagai metode etnographi, karena pada awalnya metode ini lebih banyak digunakan untuk penelitian bidang antropologi budaya; disebut sebagai metode kualitatif, karena data yang terkumpul dan analisisnya lebih bersifat kualitatif (Sugiyono, 2017:8). Data kualitatif berupa kalimat, kata, skema, pernyataan, gambar dan indeks tertentu, asalkan bukan berupa angka-angka.

Peneliti juga memakai jenis penelitian deskriptif. Menurut Sugiyono (2017:13) penelitian deskriptif yaitu penelitian yang dilakukan untuk mengetahui nilai variabel mandiri, baik satu variabel atau lebih (independen) tanpa membuat perbandingan, atau menghubungkan dengan variabel yang lain. Jenis penelitian ini dilakukan dengan cara mengumpulkan data-data untuk menguji hipotesis atau menjawab pertanyaan penelitian mengenai kondisi terakhir dari subjek penelitian. Tujuannya adalah untuk memperoleh deskripsi lengkap dan akurat dari suatu situasi.

\section{Metode Penelitian}

Peneliti menggunakan jenis metode penelitian kualitatif dengan cara data-data yang dianalisis secara kualitatif akan dikelompokkan dan diseleksi berdasarkan kualitas dan kebenarannya yang berkaitan dengan masalah yang diteliti. Dalam penelitian ini, Peneliti memaparkan satu persatu dari empat fungsi manajemen penyiaran pada program Talk Show Aiman di Kompas TV Jakarta. Ke-empat fungsi tersebut yakni perencanaan, pengorganisasian, penggerakan, dan pengawasan kegiatan penyelenggaraan siaran.

\section{Objek Penelitian}

Objek penelitian difokuskan kepada penerapan fungsi manajemen penyiaran pada program acara dengan format talk show atau bincang-bincang. Talk show tersebut yakni talk show Aiman yang yang di stasiun penyiaran Kompas TV.

\section{Sumber Data}

Sebagai upaya untuk memperoleh hasil penelitian yang akurat Peneliti menggunakan sumber data primer dan sekunder. Sumber data primer dilakukan dengan cara wawancara.

Selain itu, Peneliti juga melakukan permohonan data sekunder, yakni permintaan data-data mengenai program acara talk show Aiman dan Kompas TV. Data-data tersebut berupa struktur organisasi, visi, misi, tugas pokok dan fungsi masing masing bagian manajemen penyiarannya. 


\section{Teknik Pengumpulan Data}

Sumber data primer yang diperoleh Peneliti dengan metode wawancara dilakukan dengan memakai pedoman daftar pertanyaan yang telah disusun sebelumnya. Sedangkan sumber data sekunder yang diperoleh akan dipadukan dengan studi literatur atau sumber data penelitian yang terdahulu dan releven dengan tema penelitian ini.

\section{Teknik Analisa Data}

Analisa data pada metode penelitian kualitatif ini dilakukan dengan cara mengumpulkan semua data yang telah diperoleh untuk diproses terlebih dahulu melalui metode pencatatan, pengetikan dan penyuntingan kemudian disusun secara distematis dalam kalimat-kalimat yang diperluas. Penelitian kualitatif menekankan pada kualitas hasil penelitian karena setelah pengujian hipotesis, Peneliti dapat mengonfirmasi teori yang sudah ada, mengembangkan atau membuat teori baru.

\section{Validitas Data}

Data primer dan data sekunder yang Peneliti dapat akan diuji keabsahannya dengan cara :

1. Mengecek kembali data-data yang telah diperoleh dengan keadaan sebenarnya di lapangan. Bila diperlukan maka akan diajukan permohonan perpanjangan penelitian data di lapangan.

2. Meningkatkan kecermatan dalam penelitian. Segala sumber data yang diperoleh akan diurutkan sesuai dengan sistematis Penelitian. Sumber data akan Peneliti simpan dalam bentuk rekaman, soft file dan hard copy.

3. Menggunakan bahan referensi berupa buku-buku dan jurnal penelitian yang relevan.

4. Melakukan pengujian dependability atau mengaudit selurus proses penelitian yang dilakukan peneliti dengan reviewer atau pembimbing penelitian sehingga akan diperoleh keabsahan data-data penelitian.

\section{Teknik Pengolahan Data}

Data-data yang telah diperoleh akan diolah dalam 3 tahap, yakni :

1. Tahap penyajian data, yaitu data-data yang telah diperoleh akan dipaparkan dalam bentuk uraian yang terintegrasi satu sama lain.

2. Tahap komparasi, yaitu membandingkan kemudian membahas data hasil deskripsi berdasarkan landasan teori yang dipakai.

3. Tahap penyajian hasil penelitian, yaitu tahap merangkum data yang mengarah pada kesimpulan untuk menjawab rumusan masalah penelitian.

\section{HASIL DAN PEMBAHASAN}

Mengingat pada saat ini masih dalam kondisi pandemik virus Covid-19, maka wawancara dilakukan dengan cara berkomunikasi melalui media WA. Berdasarkan wawancara yang dilakukan peneliti dengan narasumber utama, yaitu Aiman Wicaksono, sebagai pembawa talk show AIMAN, didapatkan hasil sebagai berikut: 
Menerapkan fungsi manajemen penyiaran yaitu perencanaan, pengorganisasian, pengarahan dan memberikan pengaruh, serta pengawasan. Semua fungsi ini berhubungan erat satu sama lain untuk menghasilkan program siaran yang sesuai standar televisi butuhkan untuk menghasilkan program acara yang sesuai tujuan organisasi.

\section{Perencanaan}

Program AIMAN memiliki 5 segmen dengan durasi jam penayangan selama 60 menit. Segmen pertama memuat paket berita yang membahas isu hangat yang sedang terjadi. Pada segmen kedua dan ketiga, pembawa acara mulai melakukan penelusuran di lokasi kejadian yang dilengkapi dengan wawancara mendalam terhadap narasumber yang kompeten, tentu disertai naskah pembawaan berita. Selanjutnya pada segmen keempat, pembawa acara melakukan wawancara dengan pihak kedua yang sedang menghadapi berbagai kasus. Dan di segmen kelima atau terakhir, pembawa acara melakukan wawancara dengan pakar atau ahli dalam bidang yang bersangkutan dengan berita yang sedang dibawakan.

Program acara talk show AIMAN yang tayang setiap hari Senin pada pukul 20.00 WIB mengambil jam penayangan prime time, dimana kebanyakan orang cenderung menonton televisi setelah selesai bekerja atau makan malam. Selama prime time, biasanya permintaan iklan lebih tinggi sehingga berpengaruh terhadap anggaran pendapatan. Keputusan jam penayangan dan durasi dari suatu program acara merupakan hasil pertimbangan dari manajemen produksi yang terlebih dahulu membuat perencanaan dasar dari suatu konsep acara televisi yang akan menjadi landasan kreativitas dan desain produksi yang akan terbagi dalam berbagai kriteria utama yang disesuaikan dengan tujuan dan target pemirsa acara tersebut (Latief dan Utud , 2015:24).

Segmentasi pada program ini adalah orang dewasa direntang usia 18-40 tahun dengan jenis kelamin baik wanita maupun laki-laki dan berpendidikan cukup. dengan isi konten mengenai isu atau fenomena yang terjadi di Indonesia baik hot issues maupun current issues, baik dalam bidang politik, hukum ataupun isu sosial, talk show AIMAN menargetkan segmentasinya pada orang dewasa direntang usia 18- 40 tahun dengan jenis kelamin wanita maupun laki-laki dan berpendidikan cukup. Jangkauan wilayah penayangannya adalah di seluruh Indonesia.

Pada tahap perencanaan, strategi yang dilakukan oleh manajemen talk show AIMAN adalah mengedepankan pentingnya riset atau penelitian suatu masalah yang akan dijadikan berita atau bahan peliputan. Riset dilakukan secara mendalam karena bentuk pengemasan dari program acara talk show AIMAN adalah mengupas isu secara rinci dengan mendatangi langsung lokasi kejadian dan diadakan penelusuran atas kasus yang sedang terjadi tersebut. Liputan pengamatan suatu peristiwa dapat dilakukan berdasarkan antisipasi dari pengalaman kejadian sebelumnya atau informasi yang akurat dari sumber yang meyakinkan (Fachruddin, 2012:47). Selama penelusuran, pembawa acara akan melakukan wawancara dengan narasumber narasumber utama sebagai tokoh sentral dalam tema yang sedang dibahas. Untuk itu, tim riset harus mengumpulkan bahan liputan langsung dari data-data yang ada di lapangan, bahan pemberitaan di luar lapangan, orang-orang yang terhubung langsung dengan kejadian, dan mengolahnya menjadi paket berita yang terpercaya, lengkap serta 
disertai info grafis yang menarik. Tim riset juga dibantu oleh bahan-bahan informasi dari lembaga kompas lainnya.

Tahap perencanaan strategis dimulai dari penyusunan tujuan. Maksud dari penetapan tujuan ini adalah agar terdapat koordinasi dari berbagai kegiatan yang dilakukan oleh berbagai departemen maupun individu didalamnya dengan memperhatikan hasil akhir utama media penyiaran. Jadi, setiap kegiatan yang ada dalam media penyiaran dapat dilaksanakan secara terarah sesuai dengan tujuan akhirnya. Menurut Aiman Witjaksono, tujuan umum dari program acara talk show AIMAN yaitu terkait dengan pemanfaatan dampak dan pengaruh bagi publik. Diharapkan tayangan ini dapat memberikan manfaat baik kepada para penonton, narasumber, serta lingkungan sekitarnya.

Setiap tujuan dari suatu kegiatan pengelolaan media penyiaran mengacu kepada visi dan misi dari perusahaan. Visi dari Kompas TV ialah menjadi televisi berita yang terbaik dan paling dipercaya. Adapun misinya menyajikan program berita yang independen, kredibel, dan menjadi acuan bagi para pengambil kebijakan. Jadi, dalam setiap tayangannya manajemen talk show AIMAN menerapkan main work, bekerja sama dengan para wartawan yang mengimplementasi kode etik jurnalistik dalam pencarian bahan riset ataupun berita. Hal ini dilakukan untuk menjaga komitmen agar tayangan yang ditampilkan tetap independent dan bisa dipercaya.

Keputusan tertinggi penetapan strategi manajemen perencanaan diambil oleh pemimpin redaksi atau Aiman Witjaksono dengan memperhatikan saran dari semua pihak yang terlibat. Hal ini sesuai dengan peraturan Undang-undang Nomor 40 Tahun 1999 pasal 15 mengenai dewan pers.

\section{Pengorganisasian}

Manajemen pengorganisasi yang dijalankan secara efektif akan membantu program acara sampai ke tujuan yang ingin dicapai. Menurut Wahyudi (1994:78), organisasi penyiaran adalah tempat orang-orang penyiaran (siaran-teknik-administrasi) saling bekerja sama dalam merencanakan, memproduksi, atau mengadakan materi siaran, dan sekaligus menyiarkan dalam usaha mencapai tujuan yang telah ditetapkan. Kegiatan ini dilakukan dengan menentukan sumberdaya yang dibutuhkan berdasarkan kegiatan yang dibutuhkan untuk mencapai tujuan organisasi, menyusun rencana guna pengembangan suatu organisasi, memberikan penugasan tertentu, dan memberi pendelegasian wewenang kepada individu untuk melaksanakan tugas-tugasnya.

Berdasarkan hasil wawancara dengan Aiman Witjaksono, pengelolaan sumber daya manusia yang bekerja pada program acara talk show AIMAN diambil dalam jumlah minimal, yang penting mencukupi di setiap bagian pekerjaan. Apabila dirasa kurang, maka akan dilakukan rekrutmen, sebuah konsekuensi terhadap kebijakan anggaran pengeluaran tapi mendapat kelayakan.

Program acara talk show AIMAN menerapkan main work. Dalam media penyiaran, manajer umum bertanggungjawab pada pemilik dan pemegang saham dalam melaksanakan sumber daya yang ada, baik sumber daya manusia maupun barang. Berikut bagan organisasi yang menerapkan main work : 

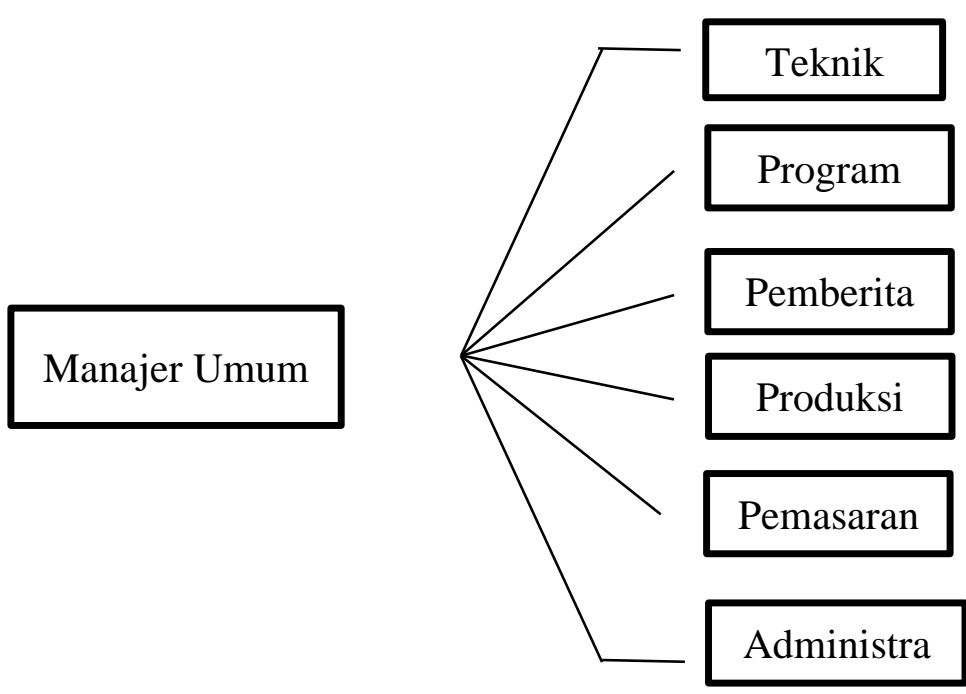

\section{Gambar 4. Bagan Organisasi yang Menerapkan Main Work} (Morissan, 2008:148)

Lebih lanjut dijelaskan oleh Aiman Witjaksono bahwa tidak ada pembagian manajemen atas, tengah, dan bawah, karena manajemen di lingkup jurnalistik itu rata.

Bagian teknik dipimpin oleh seorang kepala teknik yang bertugas melakukan koordinasi diantara berbagai kelompok teknisi. Secara umum bagian teknik melakukan kegiatan menyusun anggaran belanja peralatan produksi baru, serta melakukan jadwal perawatan perlengkapan produksi.

Bagian program bertugas merencanakan, memilih dan menyusun acara. Program acara talk show AIMAN adalah program milik Kompas TV sendiri, untuk itu bagian program bertanggungjawab pula untuk menyusun perencanakan 4P, yaitu 1) Product, materi program acara 2) Price, biaya yang harus dikeluarkan untuk memproduksi program acara serta menentukan tarif iklannya 3) Place, waktu siaran yang tepat 4) Promotions, cara untuk memasarkan program acara agar diketahui masyarakat sehingga dapat mendatangkan iklan dan sponsor.

Tanggungjawab seorang kepala manajer program mencakup pengawasan anggaran program, melakukan negosiasi dengan produser, dan mengevaluasi ide-ide lokal untuk kemungkinan diproduksi sendiri (Morissan, 2008:203)..

Bagian pemberitaan merupakan departemen yang terpisah dari bagian program karena sifatnya yang harus segera ditayangkan dan adanya misi atau tanggungjawab tertentu yang ditanggung oleh manajemen. Tanggungjawab ini terkait dengan misi stasiun televisi. Program acara talk show AIMAN mengemas tayangannya dalam bentuk penyajian program berita penelusuran mengenai hot dan current issue yang dilakukan secara independen, kredibel, dan diharapkan dapat menjadi acuan bagi para pengambil kebijakan, sesuai dengan misi Kompas TV.

Bagian pemasaran fokus pada kegiatan penjualan program kepada pemasang iklan, untuk itu diperlukan pemahaman yang luas dalam mengenali pasar dan usaha yang dilakukan oleh calon pemasang iklan dan keunggulan program acara yang ditayangkan. Guna menarik calon pemasang iklan, bagian pemasaran harus 
mampu menerangkan secara jelas dan menarik mengenai keuntungan yang akan diperoleh ketika iklan produk atau usaha mereka ditampilkan pada jangka waktu commercial break program acara talk show AIMAN. Setelah adanya kesepakatan dengan calon pemasang iklan, bagian pemasaran akan berkoordinasi dengan bagian program mengenai waktu siaran penayangan iklan. Bila ada slot iklan yang kosong, bagian pemasaran akan mengisinya dengan promo program acara ataupun iklan layanan masyarakat.

Selanjutnya adalah bagian administrasi. Bagian ini bertanggungjawab menyediakan kebutuhan yang berkaitan dengan fungsi administrasi suatu organisasi. Fungsi tersebut diantaranya pengelolaan sumber daya manusia, keuangan, serta administrasi lainnya terkait perizinan dari berbagai pihak.

\section{Pengarahan dan Memberikan Pengaruh}

Fungsi manajemen dalam melakukan pengarahan dan memberikan pengaruh sangat penting dalam meningkatkan etos kerja para karyawan.

Menurut Aiman Witjaksono, para karyawan yang bekerja pada program acara talk show AIMAN dimotivasi untuk memiliki semangat yang sama, yakni semangat dalam memberikan manfaat dan melakukan perubahan yang positif. Semangat ini bersamaan dengan adanya usaha perusahaan memberikan penghargaan berupa promosi kenaikan jabatan dan kompesasi yang memadai kepada karyawan yang mencapai target dan memiliki prestasi. Semakin tinggi tingkat kepuasan karyawan pada perusahaan, maka akan semakin besar kontribusi karyawan untuk mencapai tujuan dalam rangka memajukan perusahaan.

Komunikasi yang jelas dan terarah sangat penting bagi keberhasilan fungsi manajemen karena media penyiaran ialah lembaga yang hidup dalam bidang komunikasi. Media menyiaran merupakan perantara komunikasi massa yang menyebarkan pesan-pesan komunikasi yang didistribusikan kepada masyarakat luas, sehingga komunikasi didalamnyapun harus berlangsung sesuai tujuan. Dengan cara berkomunikasi, pemimpin dapat mengingatkan kepada karyawannya mengenai tujuan dari program acara yang sedang dijalankan dan diharapkan mereka dapat berperan aktif dalam mencapai tujuan tersebut. Begitu pula dengan para karyawan, dengan berkomunikasi mereka dapat menyampaikan bila ada hambatan, solusi pemecahan suatu masalah, ide, dan gagasan untuk kemajuan perusahaan. Komunikasi yang baik menghasilkan aliran informasi yang lancar diantar pemimpin dan para karyawannya.

Setiap hari dunia penyiaran semakin berkembang, begitu pula ilmu dan alat-alatnya, akan selalu ada pembaharuan untuk memudahkan pekerjaan, untuk itu diperlukan adanya pelatihan. Pelatihan dilakukan oleh manajemen program acara talk show AIMAN sebagai usaha untuk meningkatkan kemampuan sumber daya manusia dalam hal mempelajari ilmu dan alat-alat produksi yang baru. Kegiatan ini dilaksanakan rutin baik secara formal maupun informal dengan mendatangkan personel yang kompeten di bidangnya. Diharapkan setiap karyawan mampu mengimplementasikan hasil dari pelatihan untuk dapat bekerja secara lebih efektif sehingga dapat membantu lembaga penyiaran dalam mencapai tujuannya.

\section{Pengawasan}


Setelah rencana ditetapkan dan pelaksanaan kerja dilaksanakan, maka dibutuhkan suatu usaha untuk membandingkan hasil yang telah dicapai dengan rencana yang diinginkan untuk kemudian dilakukan tindakan perbaikan atau koreksi apabila ada hal-hal yang tidak sesuai dengan rencana awal. Tindakan perbaikan dilakukan berdasarkan dengan adanya pengawasan terhadap rencana dan pelaksanaan kerja yang disesuaikan dengan tujuan yang ingin dicapai.

Terkait dengan pengelolaan fungsi pengawasan pada sumber daya manusia yang bekerja di program acara talk show AIMAN, berdasarkan hasil wawancara dengan Aiman Witjaksono, ada tindakan proses penilaian semester dari kepala bagian masing-masing kepada bawahannya. Penilaian ini dilakukan secara berjenjang, misalnya dari manajer ke asisten manajer dalam jangka waktu 6 bulan sekali. Sebagai upaya menghindari subjektivitas, penilaian dibuat secara tertulis, ditulis atasan dan dikembalikan kepada bawahannya.

Hasil dari penilaian adalah reward berupa insentif dan atau promosi jabatan bagi pegawai yang kinerjanya meningkat atau berprestasi. Jika dalam penilaian ada hasil tidak sesuai dengan standard operating procedure (SOP) maka akan dilakukan demosi atau punishment berupa pembinaan, dari sanksi peringatan lisan, tertulis dan tindakan tegas lainnya. Namun, selama ini sangat kecil kemungkinan penilaian semester tidak sesuai dengan SOP, karena pihak manajemen juga mengadakan penilaian informal yang dilakukan setiap hari. Upaya ini sesuai dengan unsur-unsur yang ada dalam fungsi pengawasan, yaitu adanya tindakan evaluasi, penilaian dan perbaikan.

Fungsi pengawasan manajemen dalam menentukan tingkat efisiensi dan efektivitas pekerjaan suatu perusahaan penyiaran. Maksud dari efisiensi adalah kemampuan untuk menyelesaikan suatu pekerjaan dengan benar (Morissan, 2009:160). Melakukan pekerjaan secara benar berarti berhasil dalam mencapai target, produktivitas dan performance sesuai tujuan dan rencana awal. Pencapaian tersebut melebihi pengeluaran uang, tenaga kerja, perlengkapan, dan bahan-bahan yang dikeluarkan. Sedangkan efektivitas merupakan kemampuan untuk memilih tujuan dan peralatan yang tepat untuk mencapai tujuan yang telah ditetapkan. Hal ini membutuhkan kecermatan dalam berpikir langkah-langkah masa depan dari sebuah rencana kerja.

\section{SIMPULAN}

Berdasarkan hasil penelitian, dapat disimpulkan bahwa fungsi manajemen penyiaran pada program acara talk show AIMAN yang ditayangkan Kompas TV sudah diterapkan dengan baik. Fungsi perencanaan isi program acara dilakukan dengan riset yg mendalam dan penuh kehati-hatian karena tujuannya adalah memberikan kemanfaatan dari dampak dan pengaruh bagi publik yang menonton acaranya. Fungsi pengorganisasian diatur sesuai dengan undang-undang nomor 40 tentang pers, tidak ada pembagian manajemen di bagian atas, tengah, dan bawah. Sebagai penanggungjawab semuanya dan pengambilan keputusan tertinggi ialah pemimpin redaksi atau Aiman Witjaksono dengan memperhatikan saran pihak-pihak yang terlibat. Fungsi selanjutnya adalah pengarahan dan memberikan pengaruh yang diberikan pemimpin 
kepada bawahannya melalui metode motivasi, komunikasi, kepemimpinan, dan pelatihan. Semua karyawan yang bekerja di program acara talk show AIMAN diberikan motivasi yang sama, berupa semangat dalam memberikan manfaat dan melakukan perubahan yang positif. Pelatihanpun diadakan baik secara formal maupun informal. Ketiga fungsi diatas mesti harus dilakukan evalusi melalui fungsi pengawasan. Dalam menjalankan fungsi pengawasan, manajemen talk show AIMAN melakukan penilaian semester setiap 6 bulan sekali untuk mengevaluasi hasil pekerjaan dari atasan ke bawahannya

\section{DAFTAR PUSTAKA}

\section{Undang-Undang}

Undang-Undang Nomor 32 Tahun 2002 Tentang Penyiaran

Undang-Undang Nomor 40 Tahun 1999 Tentang Pers

\section{Buku}

Djamal, H \& Andi Fachruddin. (2011). Dasar-Dasar Penyiaran Sejarah, Organisasi, Operasional, dan Regulasi. Jakarta : Penerbit Kencana.

Fachruddin, Andi. (2016). Manajemen Pertelevisian Modern. Yogyakarta : CV. Andi Offset.

Febriani. (2005). Pengaruh Pengawasan terhadap Efektivitas Pelayanan Izin Mendirikan Bangunan Pada Dinas Tata Kota Bandar Lampung. Bandung: Pascasarjana UNPAD.

Handoko, T. Hani. (2011). Manajemen Personalia dan Sumberdaya Manusia. Yogyakarta: Penerbit BPFE. Kadarman. (2001). Sistem Pengawasan Managament. Jakarta: Pustaka Quantum.

Morissan,M.A. (2009). Manajemen Media Penyiaran, Strategi Mengelola Radio \& Televisi. Jakarta: Kencana Prenada Media Grup.

Latief,R. dan Y.U. (2015). Siaran Televisi Non-Drama. Jakarta: Kencana Prenada Media Group.

Sugiyono. (2017). Statistika Untuk Penelitian. Bandung: Alfabeta.

Wahyudi, J.B. (1994). Dasar-Dasar Manajemen Penyiaran. Jakarta : Gramedia Pustaka Utama.

\section{Jurnal}

Priska Enggar Kinanthi.(2015). Manajemen Media Penyiaran pada RATIH TV Kebumen. Surakarta: Universitas Sebelas Maret.

Tantri Yudhientia. (2013). Strategi Manajemen Programming Pada Stasiun Televisi Swasta Lokal JTV Surabaya. Surabaya: Universitas Airlangga.

\section{Internet}

www.kompas.tv, diakses pada tanggal 18 Januari 2020 pukul 10.15 WIB.

www.kpi.go.id/index.php/id/umum/38-dalam-negeri/35459-nama-pemenang-anugerah-kpi-2019, diakses pada tanggal 20 Januari 2020 pukul 10.45 WIB.

https://id.wikipedia.org/wiki/Kompas_TV, diakses pada tanggal 20 Januari 2020 pukul 11.48 WIB. 